\title{
Detection of Enteric Viruses on Strawberries and Raspberries Using Capture by Apolipoprotein $\mathbf{H}$
}

\author{
Anthony Lévesque ${ }^{1}$, Eric Jubinville ${ }^{1}$, Fabienne Hamon ${ }^{2}$ and Julie Jean ${ }^{1, * \mathbb{D}}$ \\ 1 Department of Food Sciences, Institute of Nutrition and Functional Foods (INAF), Université Laval, \\ Quebec, QC G1V 0A6, Canada; anthony.levesque.2@ulaval.ca (A.L.); eric.jubinville.1@ulaval.ca (E.J.) \\ 2 Food Molecular Biology RD Department, bioMérieux, 38000 Grenoble, France; \\ fabienne.hamon@biomerieux.com \\ * Correspondence: julie.jean@fsaa.ulaval.ca
}

check for updates

Citation: Lévesque, A.; Jubinville, E. Hamon, F.; Jean, J. Detection of Enteric Viruses on Strawberries and Raspberries Using Capture by Apolipoprotein H. Foods 2021, 10 , 3139. https://doi.org/10.3390/ foods10123139

Academic Editor: Andrew G. Gehring

Received: 20 October 2021

Accepted: 14 December 2021

Published: 18 December 2021

Publisher's Note: MDPI stays neutral with regard to jurisdictional claims in published maps and institutional affiliations.

Copyright: (c) 2021 by the authors. Licensee MDPI, Basel, Switzerland This article is an open access article distributed under the terms and conditions of the Creative Commons Attribution (CC BY) license (https:// creativecommons.org/licenses/by/ $4.0 /)$.

\begin{abstract}
Human noroviruses (HuNoVs) and the hepatitis A virus (HAV) are the main viral causes of foodborne illness worldwide. These viruses are frequently transmitted via fresh and frozen berries, such as strawberries and raspberries. ISO 15216:1 (2017), currently the preferred method for their detection, involves several steps and is time-consuming. Apolipoprotein $\mathrm{H}(\mathrm{ApoH})$ has been shown to have a strong affinity for several microorganisms, including HuNoVs. In this article, we report an ApoH-based method of capturing the HAV and HuNoVs adherent to berries and concentrating them for assay. The limit of detection of both viruses suspended in a buffer was low. On strawberries, the HAV was detected down to $10^{4}$ genome copies $/ 25 \mathrm{~g}$ in $100 \%$ of cases and down to $10^{3}$ genome copies $/ 25 \mathrm{~g}$ on raspberries in $50 \%$ of cases. This sensitivity was not significantly different from that of the ISO method 15216:1 (2017). HuNoV GII.4 was more difficult to detect using the ApoH method. The ApoH CaptoVIR kit does, nevertheless, appear to be usable in the near future as a single-test, multiple-detection method for viruses on fresh and frozen berries.
\end{abstract}

Keywords: capture; detection; hepatitis A virus; human norovirus; apolipoprotein H; beta-2glycoprotein-1; magnetic beads

\section{Introduction}

Human noroviruses (HuNoVs) and hepatitis A virus (HAV) are the main viral causes of diarrheal and non-diarrheal enteric illness [1]. In 2010, 120 million cases of HuNoVs and 14 million cases of HAV were reported worldwide [1]. A concerning increase in the percentage of cases involving foodborne transmission has occurred in recent years [2,3]. Soft fruits and vegetables are frequent vehicles of transmission [4] and have been implicated in several outbreaks around the world [2]. Between 1983 and 2018, 68 outbreaks of HAV or HuNoVs and over 18,000 illnesses were associated with berries [2]. Frozen berries, especially strawberries for $\mathrm{HAV}$ and raspberries for $\mathrm{HuNoVs}$, were the main vectors of these outbreaks [2]. Complete elimination of these viruses on berries would be a welcome development, but this is difficult to achieve with current inactivation methods. In the meantime, prevention of outbreaks relies on viral detection and product recall. Since viruses are usually present in very low numbers on berries, concentrating them prior to detection is a critical step. In addition, berries release multiple inhibitors of the real-time polymerase chain reaction (qPCR) [5], and these need to be removed to avoid false negative assay results. The current gold standard method for detecting viruses on berries is the ISO method 15216:1 (2017), which involves a concentration step based on precipitation with polyethylene glycol/sodium chloride (PEG/NaCl) [6]. This method can be performed routinely but requires several hours and certain technical skills. Other methods of concentration based on affinity, such as capture with ligands [7] or antibodies [8,9], or on physical separations, such as ultrafiltration [8,9] and ultracentrifugation [10], are currently in development. However, physical methods often perform poorly when the food matrix is 
complex (inclined to clog ultrafiltration membrane pores) [11] and few methods concentrate both HuNoVs and HAV with high specificity.

Apolipoprotein $\mathrm{H}(\mathrm{ApoH}$, also known as beta-2-glycoprotein I) is a plasma protein involved in antiphospholipid syndrome (APS syndrome) [12]. This protein has a broadspectrum affinity, including for hepatitis B and C viruses [13,14], HuNoVs, and many Grampositive and Gram-negative bacteria [15]. To the best of our knowledge, its affinity for HAV is unknown [15], and the possibility of using it in magnetic bead form for concentrating and detecting the HAV and HuNoVs on berries in a single method should therefore be investigated.

The purpose of this study was to investigate the affinity of ApoH for HAV and to determine the limit of detection of HAV and HuNoV GII.4 on fresh and frozen strawberries and raspberries using $\mathrm{ApoH}$ as a capture and concentration step. The ApoH method was compared to the ISO method 15216:1 (2017) using fresh strawberries and raspberries.

\section{Materials and Methods}

\subsection{Cell Culture and Virus Production}

The cytopathogenic HAV strain HM-175 was cultured on renal rhesus macaque FRhK4 cells $[16,17]$. The cells were grown as described previously [18] on Dulbecco modified Eagle's medium (DMEM) with 10\% $(v / v)$ fetal bovine serum, $200 \mathrm{mM}$ L-glutamine, essential amino acids, $1 \mathrm{M} \mathrm{N}$-2-hydroxyethylpiperazine- $N^{\prime}$-2-ethanesulfonic acid (HEPES), and penicillin-streptomycin (all culture medium products from Wisent Inc., Saint-Jean-Batiste, QC, Canada) in cell-adherent culture flasks $\left(75 \mathrm{~cm}^{2}\right)$. They were infected with HAV at a multiplicity of infection (MOI) of 0.01 and incubated at $37^{\circ} \mathrm{C}$ and $5 \% \mathrm{CO}_{2}$ for $90 \mathrm{~min}$. The medium was changed to $2 \%$ fetal bovine serum (maintenance medium) for incubation until $70-80 \%$ cell confluence was reached ( $\sim 4-5$ days). The cells were then lysed by subjecting them to 3 freeze/thaw cycles $\left(-80^{\circ} \mathrm{C}\right.$ then $37^{\circ} \mathrm{C}$ in an incubator). The supernatant was centrifuged at $1000 \times g$ for $10 \mathrm{~min}$ and aliquoted $[16,17]$. Viral titer was measured using reverse-transcriptase qPCR(RT-qPCR).

$\mathrm{HuNoV}$ was provided by the Centre Hospitalier Universitaire Dr-Georges-L.-Dumont Laboratoire de Microbiologie (Moncton, NB, Canada) in suspensions obtained by centrifuging fecal samples diluted 1:10 in phosphate-buffered saline $(1 \times \mathrm{pH} 7.0)$ at $3000 \times \mathrm{g}$ for $30 \mathrm{~min}$ at $4{ }^{\circ} \mathrm{C}$. The suspensions were aliquoted upon receipt, sent for sequencing, and stored at $-80^{\circ} \mathrm{C}$.

\subsection{Sequencing of $\mathrm{HuNoVs}$}

The norovirus was sequenced at the Plateforme d'Analyses Génomiques of the Institut de Biologie Intégrative et des Systèmes (PAG-IBIS, Université Laval, Québec, QC, Canada) using the BigDye ${ }^{\mathrm{TM}}$ Terminator v3.1 cycle sequencing kit (Applied Biosystems, Foster City, CA, USA), an ABI 3500 series analyzer (capillaries $50 \mathrm{~cm}$ ), and Chromas v2.6.6; and it was aligned using BioEdit v7.0.5.3 and BLAST with the Norovirus Genotyping Tool v2.0 (https://www.rivm.nl/mpf/typingtool/norovirus/ (accessed on 16 December 2021)). The sequence of NoV GII.4 used in this study can be retrieved using the GenBank number MZ357344.

\subsection{Viral Capture Using ApoH}

Virus Test Suspensions

A suspension of $\mathrm{HAV}$ and / or HuNoV containing about $10^{4}$ genome copies/ $\mu \mathrm{L}$ was added to distilled water to obtain the experimental titers of $10^{5}$ genome copies in $1 \mathrm{~mL}$ or $40 \mathrm{~mL}$ of sample. These dilutions were used within $30 \mathrm{~min}$.

\subsection{Artificial Contamination of Fruits}

About $10^{5}$ viral genome copies suspended in $100 \mu \mathrm{L}$ were added to $25 \mathrm{~g}$ of fresh or frozen strawberries or raspberries in a sterile stomacher bag. All experiments were 
performed in triplicate. The sample was kept at $4{ }^{\circ} \mathrm{C}$ for $30 \mathrm{~min}$ before the elution of the virus.

\subsection{Elution of Virus from Fruit}

CV-1 buffer (40 mL; ApoH CaptoVIR kit (Catalog number \#MP10022-100T, ApoH Technologies, La Grande Motte, France)) was added to the stomacher bag, which was then shaken gently for $10 \mathrm{~min}$ at room temperature on a homemade device at about 30 cycles per minute. The free liquid was recovered in a $50 \mathrm{~mL}$ tube and kept at $4{ }^{\circ} \mathrm{C}$ for $30 \mathrm{~min}$ until viral capture.

\subsection{Viral Capture}

ApoH-coated beads in $10 \mu \mathrm{L}$ of standard suspension (ApoH Technologies) were added to the CV-1 buffer, which was then shaken on a rotary mixer at $45 \mathrm{rpm}$ for $15 \mathrm{~min}$ at $4{ }^{\circ} \mathrm{C}$. The beads were trapped by placing a neodymium magnet on the outside of the tube. The free liquid in the tube was discarded, the magnet was pulled off, and the beads were resuspended in 2 mL of NucliSENS ${ }^{\circledR}$ lysis buffer (bioMérieux, Marcy-l'Étoile, France).

\subsection{Viral RNA Extraction}

The suspension of $\mathrm{ApoH}$ magnetic beads in lysis buffer was vortexed, held at $56{ }^{\circ} \mathrm{C}$ for $30 \mathrm{~min}$, and then centrifuged at $1800 \times g$ for $2 \mathrm{~min}$. Viral RNA was then extracted according to the procedure recommended by the manufacturer of the NucliSENS ${ }^{\circledR}$ miniMAG ${ }^{\circledR}$ system (bioMérieux), eluted in $100 \mu \mathrm{L}$ of NucliSENS ${ }^{\circledR}$ elution buffer 3, stirred at $1400 \mathrm{rpm}$ for 5 min at $60^{\circ} \mathrm{C}$ in a thermomixer (Eppendorf, Hamburg, Germany), and then held for $1 \mathrm{~min}$ on a magnetic stand (bioMérieux). The supernatant was stored at $-80^{\circ} \mathrm{C}$ until RT-qPCR analysis.

\section{8. $R T-q P C R$}

Viral RNA was quantified using the iTaqTM Universal Probe One-Step RT-qPCR kit (BioRad, Hercules, CA, USA). The primers (Applied Biosystems), probes, and standard plasmid RNA (IDT, Coralville, IA, USA) are listed in ISO protocol 15216:1 (2017) [6]. An Applied Biosystems 7500 Real-Time PCR Thermal Cycler was used to produce the following temperature profile: $10 \mathrm{~min}$ at $50{ }^{\circ} \mathrm{C}, 3 \mathrm{~min}$ at $95^{\circ} \mathrm{C}, 45$ cycles of $15 \mathrm{~s}$ at $95^{\circ} \mathrm{C}$, and $30 \mathrm{~s}$ at $60^{\circ} \mathrm{C}$. Standard curves were generated using 10 -fold serial dilutions of standard plasmid RNA produced for both viruses. The $\mathrm{R}^{2}$ value of each standard curve was higher than 0.98 and the slopes were between -3.10 and -3.60 . ROX was used as the reference dye. An automatic threshold was used to determine cycle quantification $(\mathrm{Cq})$ and $\Delta \mathrm{Cq}$ values. The number $\mathrm{N}$ of viral genome copies in the sample was calculated as follows:

$$
\mathrm{N}=100 \times 10 \mathrm{R}
$$

where $\mathrm{R}$ is $\Delta \mathrm{Cq} / \mathrm{M}$ and $\mathrm{M}$ is the slope of the standard curve.

\subsection{Limit of Detection}

The limit of detection of HAV was determined in $1 \mathrm{~mL}$ and $40 \mathrm{~mL}$ of CV-1 buffer (ApoH Technologies) and on the four food matrices, whereas the limit of detection of the NoV was determined only on the foods. Samples were loaded with $10^{5}, 10^{4}, 10^{3}$ or $10^{2}$ genome copies. Positive and negative extraction controls were run for each experiment (a positive control at each concentration). Results were scored as detected or undetected. A sample was considered positive when the $\mathrm{Cq}$ was $\leq 40$.

\subsection{Comparison of the ISO and ApoH Methods}

The capture efficiencies of the ISO 15216:1 (2017) and ApoH methods were compared for fresh fruit only (performed in triplicate). For this purpose, HAV and NoV GII.4 were loaded simultaneously at the lowest concentration determined in the limit of detection experiments. The ISO method was performed as described in the standard protocol [6] with mengovirus as the procedural control. Positive in triplicate and negative controls 
were run at the concentration used. Results are expressed as the log percent genome copies recovered (percent recovery).

\subsection{Statistical Analysis}

All experiments were performed independently in quadruplicate. The ISO and ApoH were compared in terms of genome copies measured by RT-qPCR. The percent recovery of the virus was based on the ratio of the sample to its positive control, as per the ISO method [6]. Significant differences were based on two-tailed, unpaired $t$-tests at $95 \%$ confidence.

\section{Results}

3.1. Investigation of the Affinity between Hepatitis A Virus and Apolipoprotein $H$

Suspended HAV bound readily to ApoH-coated beads, and the volume of CV-1 buffer had no impact on the recovery and detection of the virus (Table 1). The HAV genome was detected over the entire range of copy numbers, from $10^{5}$ to $10^{2}$ per sample. However, the number of positive samples was higher at $10^{5}$ and $10^{4}(100 \%)$ than at $10^{3}(75 \%)$ or $10^{2}$ (25\%). No sample containing only 10 genome copies was found positive (data not shown).

Table 1. Detection of the HAV using capture by ApoH beads in CV-1 buffer.

\begin{tabular}{ccccc}
\hline \multirow{2}{*}{ Sample Volume } & \multicolumn{4}{c}{ Genome Copies/Sample } \\
\cline { 2 - 4 } & $\mathbf{1 0}^{\mathbf{5}}$ & $\mathbf{1 0}^{\mathbf{4}}$ & $\mathbf{1 0}^{\mathbf{3}}$ & $\mathbf{1 0}^{\mathbf{2}}$ \\
\cline { 2 - 4 } & \multicolumn{4}{c}{ Number of Positive Samples/Number of Samples Tested } \\
\hline $1 \mathrm{~mL}$ & $4 / 4$ & $4 / 4$ & $3 / 4$ & $1 / 4$ \\
$40 \mathrm{~mL}$ & $4 / 4$ & $4 / 4$ & $3 / 4$ & $1 / 4$ \\
\hline
\end{tabular}

Samples are considered positive if the $\mathrm{Cq}$ is less than or equal to 40 . For each concentration and volume, four samples were treated with the ApoH methods. No statistical analysis was performed.

\subsection{The Limit of Detection of Hepatitis A Virus on Berries}

$\mathrm{HAV}$, presumed to be adherent to the fresh and frozen strawberries and raspberries, was captured on ApoH beads (Table 2). There was no significant difference between the numbers detected on fresh and frozen strawberries, reaching $100 \%$ in both cases at $10^{5}$ and $10^{4}$ genome copies per sample. However, freezing did make a difference in the case of raspberries, making the adherent HAV practically undetectable. The HAV on strawberries at 10 genome copies per sample was not detectable (data not shown).

Table 2. Detection of HAV on berries using capture by ApoH beads.

\begin{tabular}{ccccc}
\hline \multirow{2}{*}{ Food } & \multicolumn{4}{c}{ Genome Copies/Sample } \\
\cline { 2 - 4 } & $\mathbf{1 0 ^ { 5 }}$ & $\mathbf{1 0}^{\mathbf{4}}$ & $\mathbf{1 0}^{\mathbf{3}}$ & $\mathbf{1 0}^{\mathbf{2}}$ \\
\cline { 2 - 4 } & \multicolumn{4}{c}{ Number of Positive Samples/Number of Samples Tested } \\
\hline Fresh Strawberry & $4 / 4$ & $4 / 4$ & $0 / 4$ & $0 / 4$ \\
Frozen Strawberry & $4 / 4$ & $4 / 4$ & $0 / 4$ & $1 / 4$ \\
Fresh Raspberry & $3 / 4$ & $2 / 4$ & $2 / 4$ & $1 / 4$ \\
Frozen Raspberry & $1 / 4$ & $1 / 4$ & $0 / 4$ & $0 / 4$ \\
\hline
\end{tabular}

Samples are considered positive if the Cq is less than or equal to 40 . For each concentration and matrix, four samples were treated with the ApoH methods. No statistical analysis was performed.

\subsection{The Limit of Detection of Norovirus GII.4 on Berries}

NoV GII.4 on fresh and frozen strawberries and raspberries was captured on $\mathrm{ApoH}$ beads (Table 3). Freezing the strawberries did not interfere with the capture, certainly not at $10^{5}$ genome copies per sample. However, NoV GII.4 was almost undetectable on frozen raspberries and was detected on fresh raspberries only when the genome copy number loaded was $10^{5}$ or $10^{4}$. 
Table 3. Detection of NoV GII.4 on berries using capture by ApoH beads.

\begin{tabular}{ccccc}
\hline \multirow{2}{*}{ Food } & \multicolumn{4}{c}{ Genome Copies/Sample } \\
\cline { 2 - 5 } & $\mathbf{1 0 ^ { 5 }}$ & $\mathbf{1 0}^{\mathbf{4}}$ & $\mathbf{1 0}^{\mathbf{3}}$ & $\mathbf{1 0}^{\mathbf{2}}$ \\
\cline { 2 - 5 } & \multicolumn{4}{c}{ Number of Positive Samples/Number of Samples Tested } \\
\hline Fresh Strawberry & $4 / 4$ & $0 / 4$ & $1 / 4$ & $0 / 4$ \\
Frozen Strawberry & $4 / 4$ & $1 / 4$ & $2 / 4$ & $0 / 4$ \\
Fresh Raspberry & $2 / 4$ & $2 / 4$ & $0 / 4$ & $1 / 4$ \\
Frozen Raspberry & $1 / 4$ & $0 / 4$ & $2 / 4$ & $0 / 4$ \\
\hline
\end{tabular}

Samples are considered positive if the $\mathrm{Cq}$ is less than or equal to 40 . For each concentration and matrix four samples were treated with the ApoH methods. No statistical analysis was performed.

\subsection{Comparison of the ISO and ApoH Methods Using Strawberries}

Based on the results in Tables 2 and 3, fresh berry samples were loaded with $10^{4} \mathrm{HAV}$ genome copies and $10^{5} \mathrm{NoV}$ GII.4 genome copies. Using the ISO PEG/ $\mathrm{NaCl}$ method, we recovered $2 \%$ of the NoV and $28.5 \%$ of the HAV (Figure 1). Recovery of the mengovirus from all the samples was greater than $1 \%$, which is the limit of validity of the ISO method. Using the ApoH method, we recovered $11.4 \%$ of the NoV and $8.5 \%$ of the HAV. The difference between these two methods of viral extraction was significant for both viruses.

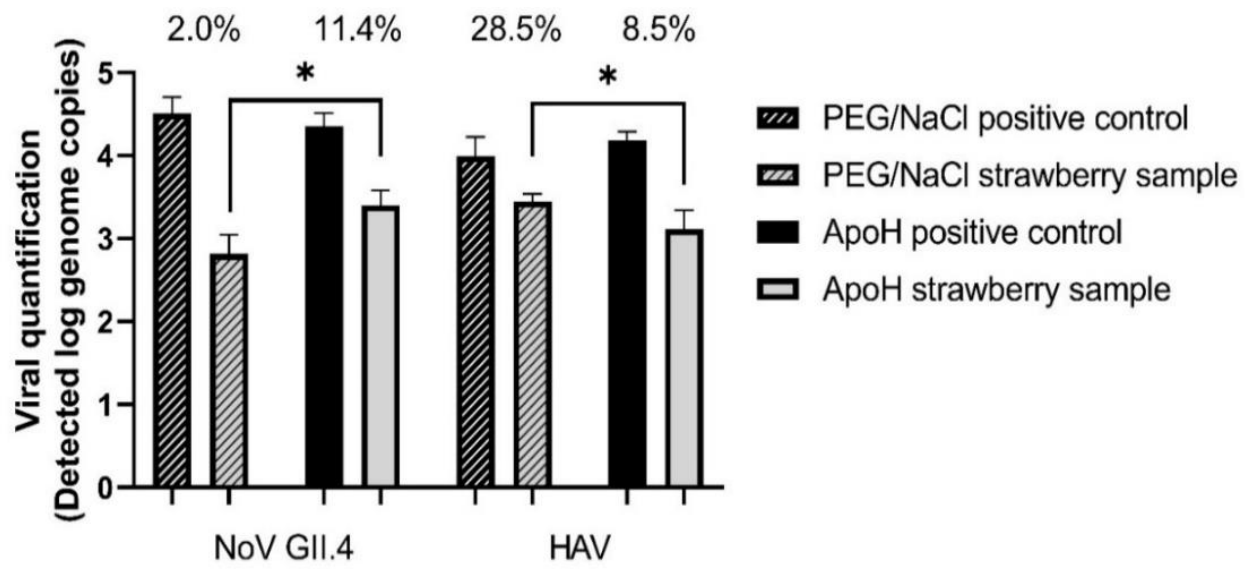

Figure 1. Simultaneous detection of HAV and NoV GII.4 on fresh strawberries using PEG/NaCl or ApoH beads to concentrate the viruses. Initial viral load at $1 \times 10^{4}$ genome copies/sample for $\mathrm{HAV}$ and at $1 \times 10^{5}$ genome copies/sample for NoV GII.4. Asterisk indicates statistically significant differences $(p \leq 0.05)$ between viral recuperation of ApoH method and ISO method based on the unpaired, two tailed $t$-test.

\subsection{Comparison of the ISO and ApoH Methods Using Raspberries}

Fresh raspberries were loaded with $10^{4} \mathrm{HAV}$ and $10^{4} \mathrm{NoV}$ GII.4 genome copies (based on Tables 2 and 3). Using the ISO PEG/ NaCl method, we recovered $21.2 \%$ of the $\mathrm{NoV}$ and $40.2 \%$ of the HAV genome copies (Figure 2). Recovery of the mengovirus was greater than $1 \%$ in all samples. Using the ApoH method, we recovered $5.4 \%$ of the NoV and $4.3 \%$ of the HAV genome copies. The difference between the two methods was not significant for $\mathrm{NoV}$ but was for HAV $(p \leq 0.001)$. 


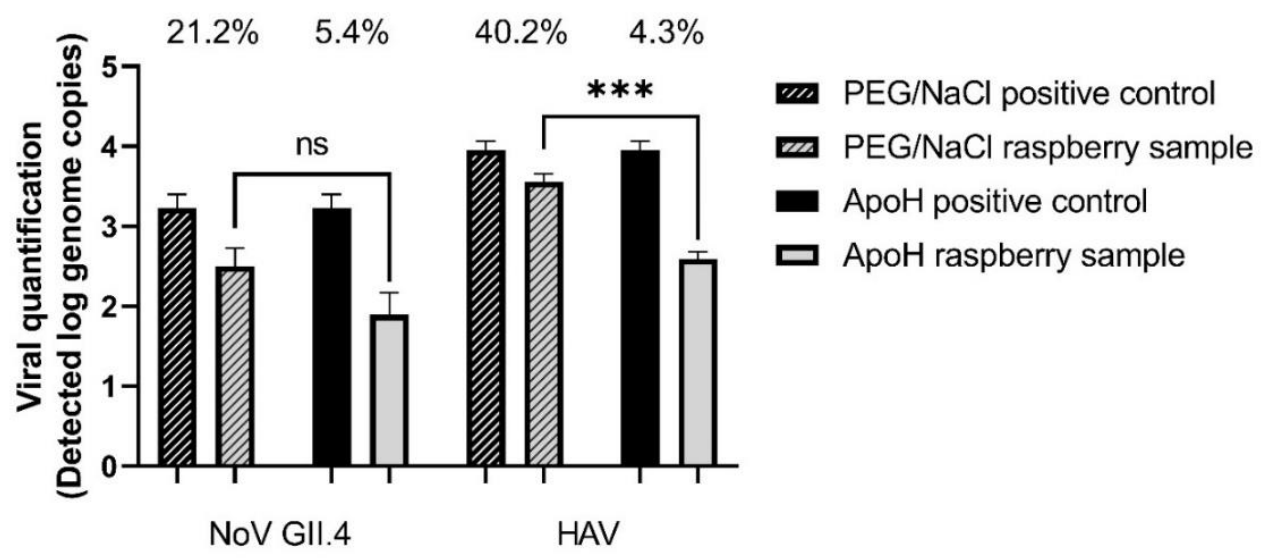

Figure 2. Simultaneous detection of HAV and NoV GII.4 on fresh raspberries using PEG/NaCl or ApoH beads to concentrate the viruses. Initial viral load at $1 \times 10^{5}$ genome copies/sample and NoV GII.4. Three asterisks indicate statistically significant differences $(p \leq 0.001)$, and ns indicates no statistically significant differences between the viral recuperation of the $\mathrm{ApoH}$ method and the ISO method based on the unpaired, two tailed $t$-test. Statistical significance is based on the unpaired, two-tailed $t$-test.

\section{Discussion}

It is important to develop a universal method to concentrate foodborne viruses and overcome the limitations inherent in the ISO method 15216:1 (2017). We proposed the use of the broad-spectrum affinity protein $\mathrm{ApoH}$, which is composed of five closely related domains, of which the fifth is rich in lysine residues [19], producing a strong positive charge at one end of the molecule, the active form of which is hook-shaped [20]. The exact role that this peculiar shape plays in the affinity of $\mathrm{ApoH}$ for viruses remains undetermined. The affinity of ApoH for anionic phospholipids is known to contribute to its involvement in APS disease [21] and could explain its binding of enveloped viruses such as HBV [13], HCV [14], and the human immunodeficiency virus [22]: all known to have membranes containing phosphatidylserine [23]. However, $\mathrm{ApoH}$ also binds microorganisms and naked viruses by a mechanism that remains unknown. We hypothesized that ionic interactions must be involved. The isoelectric points of the NoV GII and the HAV capsids fall, respectively, in the ranges 5.5-6.9 [24] and 2.8-5.5 [25,26]. At a neutral $\mathrm{pH}$ (in CV-1 buffer), these viruses should bear a negative charge and, therefore, bind readily to ApoH. One reason poor results were obtained with frozen raspberries could be that the virus was eluted at a $\mathrm{pH}$ that dropped as low as 3.0, compared to 5.0 for the fresh fruit. This drop in $\mathrm{pH}$ was smaller for the strawberry samples: 6.0 for fresh and 4.0 for frozen. Viral particles can have a neutral charge at a $\mathrm{pH}$ of 5 or 6 but would certainly have a positive charge at a $\mathrm{pH}$ of 3.0 or 4.0 (maybe neutral in the case of HAV). Shifts in surface charge, therefore, could explain the differences in the results obtained with strawberries and raspberries. It was shown that at a $\mathrm{pH}$ of 4.0, HuNoV particles tend to aggregate [27], which could make capture by ApoH more difficult. If the problem were this simple, adjusting the $\mathrm{pH}$ to neutrality before adding the ApoH beads to the suspension of the virus eluted from fruits should improve the results. Another important factor may be the detersive power of the CV-1 buffer compared to the TAS buffer used with the ApoH CaptoVIR kit (Catalog number \#MP10022-100T, ApoH Technologies, La Grande Motte). The composition of this commercial buffer is a trade secret. The CV-1 buffer appeared to dislodge the viruses more effectively from the berries (data not shown). Additional studies are required to confirm these explanations.

It is important to note the difference between our contamination protocol of frozen fruits compared to the natural contamination of berries. Berries will be contaminated prior to the freezing steps in food industries when they are fresh. So, to be as realistic as possible, fresh fruit should be contaminated and then frozen. On the other hand, if performed under laboratory conditions, freezing should be performed using the food industry's freezing 
protocol. The equipment used for this process is not easily accessible and cannot be used for experimental contaminations with foodborne pathogens. Moreover, under laboratory conditions, after the artificial contamination of fresh berries, the freezing process is slower than the one used in the food industry. This protocol could damage the matrix and would release even more inhibitors, adding fastidious purification steps.

Based on our comparison between the ISO method 15,216:1 (2017) and the ApoH method, the recovery of the $\mathrm{HuNoV}$ with $\mathrm{ApoH}$ seems to be more efficient on strawberries (Figure 1), while the data on raspberries are similar (Figure 2). However, the ISO method was better at recovering the HAV from both berries. This could be due to using TGBE buffer for viral elution in the ISO method, the $\mathrm{pH}$ thus starting at 9.5 and not decreasing much whether testing strawberries or raspberries. In addition, during the concentration step using PEG/ $\mathrm{NaCl}$, the $\mathrm{pH}$ is brought back to 7.0 , which may be ideal, depending on the isoelectric point of the viruses. This suggests that adjusting the $\mathrm{pH}$ could improve the viral capture by the $\mathrm{ApoH}$ method. Furthermore, at $\mathrm{pH} 5.0$, the pectin present in berries, particularly in raspberries, forms a strong gel [28]. Unlike the ISO method, which includes the addition of pectinase as well as adjusting the $\mathrm{pH}$ to 7.0 and is unaffected by the presence of pectin, the ApoH method could be affected by pectin. On the other hand, magnetic separation supposedly removes the virus regardless of the presence of inhibitors. In addition, we were able to capture more NoV GII.4 from the strawberries using the ApoH method, which suggests that inhibitors other than pectin affect the quantification step, giving a slight advantage to $\mathrm{ApoH}$. It is also important to consider the potential presence of other microorganisms in the HuNoV stocks, such as Gram-negative bacteria, which could compete for ApoH affinity sites and decrease HuNoV recovery [15]. Different inhibitors could also come from the diluted fecal matter in the HuNoV stock solution. This is different from the HAV stock solution that was produced from a cell culture protocol. Although not large, the difference is significant. The use of the ApoH CaptoVIR kit was described by only one published study, in which only $1 \mathrm{~mL}$ of suspension was processed and with only one virus (NoV GI or GII or Tulane virus) per test [15]. Our recoveries of NoV GII from a virus mixture were slightly lower.

The ApoH method is simpler and faster than the ISO 15216:1 (2017) method. Viral elution and capture take approximately $50 \mathrm{~min}$ compared to the ISO method's $3 \mathrm{~h}$ or more. This alone would make the $\mathrm{ApoH}$ method more suitable for routine use. It requires no chloroform/butanol or any noxious chemical and does not rely on centrifuging. Although it currently costs more than the ISO method, even at $15 \$ /$ sample, the ApoH method is advantageous due to the time saved and the ease of handling. Our results suggest that the ApoH method will facilitate and simplify the analytical workflow compared to the ISO method.

In conclusion, we demonstrated that ApoH CaptoVIR kit could be used to detect foodborne viruses in berries. Its affinity with the HAV and HuNoV make this new tool an interesting candidate in the world of foodborne viral detection methods. Furthermore, the methodology used by this kit is faster and shows a similar viral recovery rate compared to the ISO method. To the best of our knowledge, this is the first study reporting such an affinity with the HAV. Additionally, our data suggest that the ApoH CaptoVIR kit has the potential to be a single-test, multiple-detection method for viruses in fresh and frozen berries. However, further studies are necessary to optimize the method and, thus, detect viruses efficiently at lower concentrations. Investigating its potential on other food matrices, including bivalve mollusks, ready-to-eat foods, and other berries is also required. Overall, our study demonstrated a proof of concept of the potential of ApoH viral capture on food matrices.

Author Contributions: Conceptualization, A.L., E.J., J.J.; methodology, A.L.; software, A.L.; validation, E.J., J.J. and F.H.; formal analysis, A.L.; investigation, A.L.; resources, A.L.; data curation, J.J.; writing—original draft preparation, A.L.; writing—review and editing, A.L., E.J., J.J., F.H.; visualization, E.J.; supervision, E.J., J.J. and F.H.; project administration, E.J.; funding acquisition, J.J. All authors have read and agreed to the published version of the manuscript. 
Funding: Funding for this study was received in the form of research grants from the Natural Sciences and Engineering Research Council of Canada (NSERC, RDCPJ 522816-17); Consortium de recherche et innovations en bioprocédés industriel au Québec (CRIBIQ 2017-038-C29); bioMérieux, Eurofins EnvironeX; and Nature's Touch.

Institutional Review Board Statement: Not applicable.

Informed Consent Statement: Not applicable.

Data Availability Statement: The sequence of the norovirus GII.4 used in this study is available via GenBanK as number MZ357344. The raw data supporting the conclusions of this article will be made available by the authors without undue reservation.

Acknowledgments: We thank the Georges L. Dumont University Hospital Centre in New Brunswick for kindly providing us with human norovirus samples. We also thank the Institute of Nutrition and Functional Foods (INAF), the Conseil de la transformation alimentaire du Québec (CTAQ), and the Initia Foundation for graduate scholarships. Special thanks to Coralie Goetz and Stephen Davids for proofreading this article.

Conflicts of Interest: The authors have no conflict of interest to declare regarding any aspect of the planning or execution of this study or the reporting of its results.

\section{References}

1. World Health Organization. WHO Estimates of the Global Burden of Foodborne Diseases_Foodborne Disease Burdent Epidemiology Reference Group 2007-2015; World Health Organization: Geneva, Switzerland, 2015; p. 254.

2. Bozkurt, H.; Phan-Thien, K.Y.; van Ogtrop, F.; Bell, T.; McConchie, R. Outbreaks, occurrence, and control of norovirus and hepatitis a virus contamination in berries: A review. Crit. Rev. Food Sci. Nutr. 2021, 61, 116-138. [CrossRef]

3. World Health Organization. Global Health Sector Strategy on Viral Hepatitis 2016-2021. Towards Ending Viral Hepatitis; World Health Organization: Geneva, Switzerland, 2016.

4. World Health Organization; Food and Agriculture Organization of the United Nations. Microbiological Hazards in Fresh Fruits and Vegetables; World Health Organization: Geneva, Switzerland, 2008.

5. Schrader, C.; Schielke, A.; Ellerbroek, L.; Johne, R. PCR inhibitors-Occurrence, properties and removal. J. Appl. Microbiol. 2012, 113, 1014-1026. [CrossRef] [PubMed]

6. International Organization for Standardization. ISO 15216-1. Microbiology of the Food Chain-Horizontal Method for Determination of Hepatitis A Virus and Norovirus Using Real-Time RT-PCR_Part 1: Method for Quantification; ISO: London, UK, 2017. Available online: https: / / www.iso.org/standard/65681.html (accessed on 16 December 2021).

7. Morton, V.; Jean, J.; Farber, J.; Mattison, K. Detection of noroviruses in ready-to-eat foods by using carbohydrate-coated magnetic beads. Appl. Environ. Microbiol. 2009, 75, 4641-4643. [CrossRef] [PubMed]

8. Cheng, D.; Zou, S.; Liao, N.; Shi, X.; Chen, J.; Zhang, Y.; Sun, L.; Zhang, R. Evaluation of an Extraction Method for the Detection of GI and GII Noroviruses in Fruit and Vegetable Salads. J. Food Sci. 2018, 83, 393-400. [CrossRef]

9. Bartsch, C.; Szabo, K.; Dinh-Thanh, M.; Schrader, C.; Trojnar, E.; Johne, R. Comparison and optimization of detection methods for noroviruses in frozen strawberries containing different amounts of RT-PCR inhibitors. Food Microbiol. 2016, 60, 124-130. [CrossRef] [PubMed]

10. Williams-Woods, J.; Hartman, G.; Burkhardt, W., III. Bacteriological Analytical Manual Chapter 26B: Detection of Hepatitis A Virus in Foods. BAM 26B; 2017. Available online: https:/ / www.fda.gov/food/laboratory-methods-food/bam-chapter-26bdetection-hepatitis-virus-foods (accessed on 16 December 2021).

11. Summa, M.; von Bonsdorff, C.H.; Maunula, L. Evaluation of four virus recovery methods for detecting noroviruses on fresh lettuce, sliced ham, and frozen raspberries. J. Virol. Methods 2012, 183, 154-160. [CrossRef] [PubMed]

12. Grossi, C.; Artusi, C.; Meroni, P.; Borghi, M.O.; Neglia, L.; Lonati, P.A.; Oggioni, M.; Tedesco, F.; De Simoni, M.G.; Fumagalli, S. Beta2 glycoprotein I participates in phagocytosis of apoptotic neurons and in vascular injury in experimental brain stroke. $J$. Cereb. Blood Flow Metab. 2021, 41, 271678X20984551. [CrossRef]

13. Liu, Y.; Maiers, J.L.; Rui, Y.; Jiang, X.; Guleng, B.; Ren, J. Apolipoprotein H drives hepatitis B surface antigen retention and endoplasmic reticulum stress during hepatitis B virus infection. Int. J. Biochem. Cell Biol. 2021, 131, 105906. [CrossRef]

14. Stefas, I.; Tigrett, S.; Dubois, G.; Kaiser, M.; Lucarz, E.; Gobby, D.; Bray, D.; Ellerbrok, H.; Zarski, J.P.; Veas, F. Interactions between Hepatitis C Virus and the Human Apolipoprotein H Acute Phase Protein: A Tool for a Sensitive Detection of the Virus. PLoS ONE 2015, 10, e0140900. [CrossRef]

15. Almand, E.A.; Goulter, R.M.; Jaykus, L.A. Capture and concentration of viral and bacterial foodborne pathogens using apolipoprotein H. J. Microbiol. Methods 2016, 128, 88-95. [CrossRef]

16. Mbithi, J.N.; Springthorpe, V.S.; Sattar, S.A. Effect of relative humidity and air temperature on survival of hepatitis A virus on environmental surfaces. Appl. Environ. Microbiol. 1991, 57, 1394-1399. [CrossRef] 
17. Mbithi, J.N.; Springthorpe, V.S.; Boulet, J.R.; Sattar, S.A. Survival of hepatitis A virus on human hands and its transfer on contact with animate and inanimate surfaces. J. Clin. Microbiol. 1992, 30, 757-763. [CrossRef]

18. Jean, J.; Morales-Rayas, R.; Anoman, M.N.; Lamhoujeb, S. Inactivation of hepatitis A virus and norovirus surrogate in suspension and on food-contact surfaces using pulsed UV light (pulsed light inactivation of food-borne viruses). Food Microbiol. 2011, 28, 568-572. [CrossRef]

19. Schwarzenbacher, R.; Zeth, K.; Diederichs, K.; Gries, A.; Kostner, G.M.; Laggner, P.; Prassl, R. Crystal structure of human beta2-glycoprotein I: Implications for phospholipid binding and the antiphospholipid syndrome. EMBO J. 1999, 18, 6228-6239. [CrossRef]

20. Bouma, B.; de Groot, P.G.; van den Elsen, J.M.; Ravelli, R.B.; Schouten, A.; Simmelink, M.J.; Derksen, R.H.; Kroon, J.; Gros, P. Adhesion mechanism of human beta(2)-glycoprotein I to phospholipids based on its crystal structure. EMBO J. 1999, 18, 5166-5174. [CrossRef] [PubMed]

21. Kolyada, A.; Lee, C.J.; De Biasio, A.; Beglova, N. A novel dimeric inhibitor targeting Beta2GPI in Beta2GPI/antibody complexes implicated in antiphospholipid syndrome. PLoS ONE 2010, 5, e15345. [CrossRef] [PubMed]

22. Stefas, E.; Rucheton, M.; Graafland, H.; Moynier, M.; Sompeyrac, C.; Bahraoui, E.M.; Veas, F. Human plasmatic apolipoprotein H binds human immunodeficiency virus type 1 and type 2 proteins. AIDS Res. Hum. Retrovir. 1997, 13, 97-104. [CrossRef]

23. Luteijn, R.D.; Praest, P.; Thiele, F.; Sadasivam, S.M.; Singethan, K.; Drijfhout, J.W.; Bach, C.; de Boer, S.M.; Lebbink, R.J.; Tao, S.; et al. A Broad-Spectrum Antiviral Peptide Blocks Infection of Viruses by Binding to Phosphatidylserine in the Viral Envelope. Cells 2020, 9, 1989. [CrossRef]

24. Goodridge, L.; Goodridge, C.; Wu, J.; Griffiths, M.; Pawliszyn, J. Isoelectric point determination of norovirus virus-like particles by capillary isoelectric focusing with whole column imaging detection. Anal. Chem. 2004, 76, 48-52. [CrossRef]

25. Kusov, Y.; Gauss-Muller, V.; Morace, G. Immunogenic epitopes on the surface of the hepatitis A virus capsid: Impact of secondary structure and/or isoelectric point on chimeric virus assembly. Virus Res. 2007, 130, 296-302. [CrossRef]

26. Michen, B.; Graule, T. Isoelectric points of viruses. J. Appl. Microbiol. 2010, 109, 388-397. [CrossRef] [PubMed]

27. Samandoulgou, I.; Fliss, I.; Jean, J. Zeta Potential and Aggregation of Virus-Like Particle of Human Norovirus and Feline Calicivirus Under Different Physicochemical Conditions. Food Environ. Virol. 2015, 7, 249-260. [CrossRef] [PubMed]

28. Han, W.; Meng, Y.; Hu, C.; Dong, G.; Qu, Y.; Deng, H.; Guo, Y. Mathematical model of $\mathrm{Ca}^{2+}$ concentration, $\mathrm{pH}$, pectin concentration and soluble solids (sucrose) on the gelation of low methoxyl pectin. Food Hydrocoll. 2017, 66, 37-48. [CrossRef] 